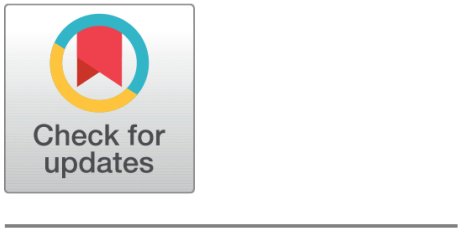

G OPEN ACCESS

Received: 29-03-2020

Accepted: 23-04-2020

Published: 02-05-2020

Editor: Dr. Natarajan Gajendran

Citation: Aslam S, Hayat N, Ali A (2020) Hybrid warfare and social media: need and scope of digital literacy. Indian Journal of Science and Technology 13(12): 1293-1299. h ttps://doi.org/

10.17485/IJST/v13i12.43

* Corresponding author. Shahbaz Aslam

PhD Scholar, School of Media \& Communication Studies, University of Central Punjab, 54000, Lahore, Pakistan

shahbaz_vu@yahoo.com1

Funding: None

Competing Interests: None

Copyright: @ 2020 Aslam, Hayat, Ali. This is an open access article distributed under the terms of the Creative Commons Attribution License, which permits unrestricted use, distribution, and reproduction in any medium, provided the original author and source are credited.

Published By Indian Society for Education and Environment (iSee)

\section{Hybrid warfare and social media: need and scope of digital literacy}

\author{
Shahbaz Aslam ${ }^{1 *}$, Noor Hayat ${ }^{2}$, Arshad Ali $^{3}$ \\ 1 PhD Scholar, School of Media \& Communication Studies, University of Central Punjab, \\ 54000, Lahore, Pakistan \\ 2 Assistant Professor, School of Media \& Communication Studies, University of Central Pun- \\ jab, 54000, Lahore, Pakistan \\ 3 Assistant Professor, School of Media \& Communication Studies, University of Gujrat, 50700, \\ Gujrat, Pakistan
}

\section{Abstract}

Background/Objectives: With the advent of communication technologies and emergence of web 2.0, the dynamics of war are also shifting from traditional warfare to information warfare. Therefore, the role of modern information and communication technologies is very important to study in the context of hybrid warfare where social media is being used as an effective weapon. This study aimed to highlight the problems and need of information literacy among the social media users of Pakistan. Conceptually, the study will take roots from hybrid war literature and digital literacy. Method: Methodologically, a survey from the social media users of Pakistan has been carried out for this study. As part of the study, development of a Hybrid War Awareness and Digital Literacy Scales to understand, detect and respond to the hybrid threats was done. Population of the study were the university students of Punjab in Pakistan. Purposively selection of 300 respondents (Male=164, Female=136) from three universities of Punjab: University of the Punjab, Lahore $(N=106)$, University of Gujrat, Gujrat ( $N=122)$ and University of Sialkot, Sialkot $(N=72)$. Students were included from BS programs $(\mathrm{N}=168)$, Master programs $(\mathrm{N}=102)$, and M.Phil. /Ph.D. Programs $(\mathrm{N}=30)$. Data was collected with the help of questionnaires. Findings: The study indicates that university students are being exposed to propaganda messages. The study reveals that university students are active in functional use of social media. Therefore, this alarming situation demands the enhancement of digital media skills among the students of higher education through proper training and learning. Moreover, critical and creative abilities of students are less as compared to the functional abilities of students in consuming social media or internet. Recommendations: Critical and creative abilities are to be enhanced for countering compete the hybrid warfare on social media.

Keywords: Hybrid War; Propaganda; Digital Literacy; Social Media 


\section{Introduction}

Media is considered as fourth pillar of society. It is often credited to unite, build national integrity and harmony in any society. However, media commercialization and privatization has transformed media into an industry. New media technologies have changed the landscape of media environment from nationally regulated media landscape to a more internationally (or inter-regionally) oriented, from public-oriented media to private owned media, from a supply-oriented media landscape into a more demand-oriented market, from mass media technologies to interpersonal media technologies (Scientific Council for Government Policy, 2005). The convergence of digital and traditional media provides an excellent platform for inclusion, participation, and transparency; which are, however, coupled with challenges previously unseen like uneven access, misinformation, and exposure to harmful content. Hence, accuracy and objectivity of information got compromised which is a serious threat for the social system ${ }^{(1)}$. Pakistani society is also facing the challenges of information explosion and social media revolution.

With the emergence of web 2.0, the individuals are not engaged passively at the receiving and consuming yet are also creating, developing, sharing and criticizing the content produced and published over digital platforms. Hence, in this scenario there is strong need that the users should know socio-cultural and emotional aspects of new media beyond its technical characteristics due to its sensitive and ever expanding nature ${ }^{(2)}$. Availability of a medium that can be exploited to pursue individuals and organization's vested interest and motives caused to build information environment where accuracy got highly compromised ${ }^{(3)}$.

With the changing landscape of communication, the concepts related to information sharing and information security also got changed. Now the information security emerged as an important concept aimed at securing people from information overload and propaganda against distort and pervert public opinion due to enhanced communication technologies ${ }^{(4)}$. Utilization of social media by the terrorist groups like ISIS for recruiting citizens, even in advanced countries of Europe and America proved its effectiveness as well as sensitivity ${ }^{(5)}$. The emergence of social media changed the nature of conflicts by changing the very nature of winning and losing of a battle and making it more complex. It has been observed that state, as well as non-state actors utilize tools of social media for propaganda and information dissemination along with other tools ${ }^{(6)}$. Military and political aims are fulfilled by utilization of different strategies of skillful combination of military operations with economic pressures, cyber-attacks and propaganda etc. The virtual platforms or social media have now become the major part of warfare.

\subsection{Hybrid war and social media}

Technological and human development has influenced the arena of wars and conflicts, as the machine guns and tanks are now replaced by the arms which cannot be seen ${ }^{(7)}$. Information environment witnessed dramatic changes in recent times hence the nature of mass communication has also changed from being a 'single authority speaking and many listening' to a 'many speak to many listeners'. The key players of information space are no more the sole information providers like Governments and traditional media rather they have to compete and get their own place ${ }^{(6)}$. Albeit it seems not justifiable to claim social media as effective as main stream media yet the role of social media is quiet prominent in terms of flow of information ${ }^{(8)}$.

Social media has the power to disseminate content in high volume with rapid speed and in short time hence used as an effective tool of hybrid warfare to influence and change the attitudes, opinions and behavior of public to fulfill certain political or military objectives. Being anonymous, the user can freely express opinion without fearing any responsibility and without any geographical or content related boundaries. Hence, the state as well as non-state actors started extensive use of social media to propagate their ideology to influence thoughts and beliefs of the targeted audience ${ }^{(8)}$. The concept of unconventional or hybrid warfare is often used to describe 'the complexity and characteristics of modern conflicts in which both state and non-state actors combine conventional methods with methods that lie outside of our traditional understanding of military operation in their war fighting strategies' ${ }^{\prime}(9)$.

Social media's ability to replicate information at high speeds with low costs, as well as difficultly to authenticate accuracy and sources of information, social media has become most effective propaganda tool for achieving specific military objectives in specific conflicts ${ }^{(10)}$. According to Nissen ${ }^{(11)}$ there are six ways that social media can be used to support military operations i.e. Intelligence Collection, Targeting, Inform and Influence (Psychological Warfare), Cyber Operations, Defense, and Command and Control. All of these doings, regardless of their impact and effect, can be accomplished through digital media. Hence, hybrid wars represent the various forms of tactics and strategies, the simultaneous military and cyber-attacks, the instantaneity of targeting, inflicting damage and all these facilitated by globalization and development of information technology ${ }^{(12)}$.

Similarly, social media can be used by the militant and terrorist groups to fulfill their own specific objectives which should be countered through the effectively educating the users regarding new media and to make them equip with skill to identify propaganda from real information as well as authenticity of the sources of information. This shows the arena of war and propaganda got expanded to the digital world hence there is a strong need to educate people to differentiate among information, misinformation and disinformation by equipping them with the skill of new media literacy. 


\subsection{Digital literacy or $\mathbf{n}$ ew media literacy}

In the age of information rather information overload, media literacy can be a useful tool to protect the society from destructive capabilities of the media. Livingstone ${ }^{(13)}$ defines the media literacy as 'the ability to access, analyze, evaluate and create messages across a variety of contexts.' 'Media literacy provides a framework to access, analyze, evaluate and create messages in a variety of forms - from print to video to the Internet. Media literacy builds an understanding of the role of media in society as well as essential skills of inquiry and self-expression necessary for citizens of a democracy'(14). Media literacy principles should not detract from your enjoyment of programs, but rather enhance your appreciation of media content ${ }^{(15)}$. It provides understanding about the role of media in democratic society. Its major elements are; (i) the symbolic and material representation of knowledge, culture and values; (ii) the diffusion of interpretative skills and abilities across a (stratified) population; and (iii) the institutional, especially, the state management of the power that it access to and skilled use of knowledge brings to those who are 'literate' ${ }^{\text {'(16) }}$.

The information and communication technologies empowered users having access to a computer or a smartphone to create and disseminate information globally over the internet and social media platforms. Albeit is considered as a great development towards information and knowledge sharing yet it also challenged the modern civil societies. The first challenge being faced is the information overload i.e. the amount of information that floods over users of modern communication platforms makes it difficult rather impossible to differentiate and evaluate reliable and fabricated information. The second challenge is that new technologies enable users to create and share information that seems authoritative and which can be viral spread of information over the various platforms. The third challenge being faced by the modern information dissemination platforms is the conflict between speed and accuracy. The desire to quickly share and access information results in compromising accuracy of the information. The fourth challenge that is being faced by the users of the modern communication platforms is the selection of preferred information that seem in congruence of the user's existing beliefs and ideas ${ }^{(4)}$.

The rise of web 2.0 and new social media platforms with the flexibility to create and disseminate the content by every user, the demand has risen to educate people towards a new kind of learning, i.e. 'new media literacy' (NML). It is a concept involving a sequence of critical skills needed for living and working in digital society of the $21^{\text {st }}$ century ${ }^{(17)}$. The users of social media are not considered as passive receivers like traditional media consumers rather empowered to create and share media content over social media hence must be able to critically evaluate the information received and shared over the cyberspace. New media literacy involves a set of skills that are required for participating in the mediated and participatory online society ${ }^{(2)}$. According to Eshet ${ }^{(18)}$ 'digital literacy is a multidimensional concept that comprised technical, cognitive, motoric, sociological, and emotional aspects and a digitally-literate person should have the ability to understand the graphical or visual messages, creating expressive media content, construction of knowledge from complex and flexible hypermedia domains, ability to judge the accuracy and quality of content, socio-emotional skills to communicate and work with others in the cyberspace as well as real-time thinking i.e. to processing multiple kinds of multimedia stimuli or multitasking.

\subsection{Objectives of study}

Followings are the major objectives of this study.

- To study the use of social media among university students.

- To investigate the students' exposure towards misinformation regarding security forces of Pakistan.

- To measure the awareness of students about critical and creative social media content about security forces.

- To explore the role of digital media skills in encountering propaganda against security forces.

\subsection{Research questions}

RQ1: To what extent university students are aware about the usage of social media?

RQ2: To what extent students critically evaluate the social media messages?

RQ3: To what extent students participate in encountering social media propaganda against security forces?

RQ4: To what extent students participate actively in promoting counter narrative against terrorism and extremism?

\section{Methodology}

Quantitative survey method was used in this study to explore the relationship between digital media literacy factors and promoting counter narrative of terrorism. Population of the study are the university students of Punjab in Pakistan. We purposively selected 300 respondents (Male=164, Female=136) from three universities of Punjab: University of the Punjab, Lahore $(\mathrm{N}=106)$, University of Gujrat, Gujrat ( $\mathrm{N}=122)$, University of Sialkot, Sialkot $(\mathrm{N}=72)$. Students were included from BS programs $(\mathrm{N}=168)$, 
Master programs $(\mathrm{N}=102)$, and M.Phil. /Ph.D. Programs $(\mathrm{N}=30)$. Data was collected with the help of questionnaire with the help of three research assistants.

\subsection{Instrument}

Demographic sheets involving scale for functional skills of social media, scale for critical skills of social media, scale for creative skills of social media and scale for critical-creative skills of social media with reference to security forces of Pakistan, were created. Validity of the instrument was ensured with expert opinion of $2 \mathrm{PhDs}$ in mass communication from public sector universities.

\subsection{Demographic sheet}

This sheet included information regarding gender, age, study program and city of the respondents. Privacy and secrecy of personal demographic information was informed and ensured to the respondents.

\subsection{Scale for social media functional use}

A six items scale (Cronbach alpha 0.71) to measure the functional or basic use of social media was used. Question items were about; use of social media, information seeking on social media, socio-political view of social media messages, social media consumption skills, and exposure to social media content related to security forces. All items were measured on Likert scale.

\subsection{Scale for social media critical use}

A six items scale (Cronbach alpha 0.73) was developed to measure the critical use of social media. Question items were about; critical use of social media, information evaluation on social media messages about security forces including authenticity, source identification, fake information, strategic aspects of messages and harmful effects of sharing of misinformation about security forces on social media. All items were measured on Likert scale.

\subsection{Scale for creative use of social media}

The five items scale developed (Cronbach alpha 0.71) to measure the creative skills for social media usage included question items about the ability of technical features of social media; content liking, sharing, use of software, content creation, and reporting the content. All these items were measured on Likert scale.

\subsection{Scale for critical creative use of media}

A five items scale (Cronbach alpha 0.72) to measure the creative use of social media for encountering propaganda against armed forces, opinion making in favor of security forces, defending security institutions and promoting counter narrative of terrorism and extremism was used. All items were measured on Likert scale.

\section{Findings and Discussion}

Media plays a major role in influencing the society. In this digital age of social media and information technology, it cannot avoided in the lives of the citizens. Media is bringing education, economic, political, and socio-cultural benefits to society, but on the other side, it is disrupting social values and norms of society by promoting negative aspects. Moreover, social media has brought an information explosion and revolution in modern societies. Its regulation and control through government or organizational bodies have become very challenging. Scholars find its solution in media literacy ${ }^{(13-15)}$. Therefore, its role has also become crucial in the age of hybrid war. Present study was designed to assess the role of media literacy in social media age.

Table 1 shows that university students have awareness about the basic use of social media. And they are using social media effectively for information seeking and sharing specifically about the security forces $(\mathrm{M}=19.06, \mathrm{SD}=7.66)$. It also reveals that university students have the ability to evaluate critically social media messages, their content, sources and spreaders ( $M=18.09$, $\mathrm{SD}=7.22$ ). Moreover, university students are technically literate to use basic social media features; profile making, accounts creating, software using for content writing, creating and dissemination by using sharing, liking, commenting and reporting content $(\mathrm{M}=14.05, \mathrm{SD}=5.66)$. They are also using their critical and creative abilities to encounter fake propaganda against security forces of Pakistan, moreover, they also participate actively in defending security forces and promoting counter narrative of terrorism and extremism on social media $(\mathrm{M}=14.34, \mathrm{SD}=5.43)$. 
Table 1. Descriptive of scales

\begin{tabular}{llllllll}
\hline \multicolumn{1}{c}{ Descriptive Statistics } \\
\hline & Items & Range & Min. & Max. & Mean & SD & $\alpha$ \\
Functional Skills & 6 & 25.00 & 5.00 & 30.00 & 19.06 & 7.66 & 0.71 \\
Critical Skills & 6 & 24.00 & 5.00 & 29.00 & 18.09 & 7.22 & 0.73 \\
Creative Skills & 5 & 20.00 & 5.00 & 25.00 & 14.05 & 5.66 & 0.71 \\
Critical Creative Skills & 4 & 20.00 & 5.00 & 25.00 & 14.34 & 5.43 & 0.72 \\
\hline
\end{tabular}

In this way they are actively participating in the hybrid warfare. However, Table 2 shows that male students are more active, critical, creative and disseminators of content on social media as compare to the female students. Therefore, it is needed to formulate policy regarding the enhancement of digital media literacy among the female students.

Table 2. Gender differences in functional, critical, creative and critical creative skills of social media

\begin{tabular}{|c|c|c|c|c|c|}
\hline & $\begin{array}{l}\text { Gender of Respon- } \\
\text { dent }\end{array}$ & $\mathrm{N}$ & Mean & SD & \\
\hline \multirow{2}{*}{ Functional Skills } & Male & 164 & 20.86 & 7.00 & $\mathrm{t}=4.63^{\star \star}$ \\
\hline & Female & 136 & 16.88 & 7.88 & \\
\hline \multirow{2}{*}{ Critical Skills } & Male & 164 & 19.64 & 6.70 & $\mathrm{t}=4.20^{* *}$ \\
\hline & Female & 136 & 16.22 & 7.40 & \\
\hline \multirow{2}{*}{ Creative Skills } & Male & 164 & 14.76 & 5.28 & $\mathrm{t}=2.41^{\star *}$ \\
\hline & Female & 136 & 13.19 & 6.00 & \\
\hline \multirow{2}{*}{$\begin{array}{l}\text { Critical Creative } \\
\text { Skills }\end{array}$} & Male & 164 & 15.43 & 5.30793 & $\mathrm{t}=3.91^{\star *}$ \\
\hline & Female & 136 & 13.02 & 5.31098 & \\
\hline
\end{tabular}

${ }^{*}$ Differences are significant at 0.01 Level.

Table 3 further demonstrates that education level is also significant for enhancing digital media literacy and active participation in the hybrid warfare. Masters and $\mathrm{MPhil} / \mathrm{PhD}$ students are more active, creative, critical and disseminators as compared to the BS students. Therefore, in this study, we argue that education is a significant factor about the study of digital media literacy skills and hybrid warfare.

Table 3. Education differences in functional, critical, creative and critical creative skills of social media

\begin{tabular}{|c|c|c|c|c|c|}
\hline & & $\mathrm{N}$ & Mean & SD & \\
\hline \multirow{4}{*}{ Functional Skills } & BS Student & 168 & 16.94 & 8.32 & \multirow{4}{*}{$\mathrm{F}=17.34^{\star *}$} \\
\hline & Master Student & 102 & 21.23 & 5.73 & \\
\hline & MPhil PhD Student & 30 & 23.53 & 5.35 & \\
\hline & Total & 300 & 19.06 & 7.66 & \\
\hline \multirow{4}{*}{ Critical Skills } & BS Student & 168 & 16.86 & 7.88 & \multirow{4}{*}{$\mathrm{F}=5.65^{\star *}$} \\
\hline & Master Student & 102 & 19.64 & 5.96 & \\
\hline & MPhil PhD Student & 30 & 19.66 & 6.03 & \\
\hline & Total & 300 & 18.09 & 7.22 & \\
\hline \multirow{4}{*}{ Creative Skills } & BS Student & 168 & 12.59 & 5.54 & \multirow{4}{*}{$\mathrm{F}=15.66^{* *}$} \\
\hline & Master Student & 102 & 16.39 & 5.37 & \\
\hline & MPhil PhD Student & 30 & 14.26 & 4.66 & \\
\hline & Total & 300 & 14.05 & 5.66 & \\
\hline \multirow{4}{*}{ Critical Creative Skills } & BS Student & 168 & 13.53 & 5.31 & \multirow{4}{*}{$\mathrm{F}=8.28^{\star *}$} \\
\hline & Master Student & 102 & 14.68 & 5.31 & \\
\hline & MPhil PhD Student & 30 & 17.73 & 5.20 & \\
\hline & Total & 300 & 14.34 & 5.43 & \\
\hline
\end{tabular}

${ }^{* * D i f f e r e n c e s}$ are significant at 0.01 Level. 
Education should be promoted to win the hybrid warfare specifically the information war on social media.

Further, we found that age does not matter in digital media literacy skills about the security forces ( Table 4 ). We found that Functional skills of social media usage are correlated to the critical skills, creative skills and critical creative skills significantly ( Table 4). Therefore, we argue that if a person is more capable of using social media effectively, the person would become good evaluator and critic of social media messages about the security forces. He/she may evaluate the information in terms of message content, authenticity, source of information. In this way, the person can encounter the hidden propaganda against security forces of Pakistan on social media.

Table 4. Relationships among the Functional Skills, Critical Skills, Creative Skills and Critical Creative Skills of University Students

\begin{tabular}{lllll}
\hline & Functional Skills & Critical Skills & Creative Skills & Critical Creative Skills \\
\hline Age of Respondent & -.094 & .108 & -.042 & -.039 \\
Functional Skills & 1 & $.784^{* *}$ & $.756^{* *}$ & $.476^{* *}$ \\
Critical Skills & $.784^{* *}$ & 1 & $.643^{* *}$ & $.539^{* *}$ \\
Creative Skills & $.756^{* *}$ & $.643^{* *}$ & 1 & $.484^{* *}$ \\
\hline
\end{tabular}

${ }^{* *}$ Correlation is significant at the 0.01 level (2-tailed).

Similarly, this study also found that critical skills of a person lead him/her towards the creative skills of social media, the person will be engaged more in the content creating and dissemination in the favor of security forces ( Table 4). If a person becomes more creative user of social media, then he/she is the active defender and opinion warrior of security forces in cyberspace. The person will use social media more effectively for encountering propaganda against security forces and for the creation and dissemination of social media content and messages in favor of security forces.

Tables 5 and 6 shows that digital media literacy skills can significantly predict the encountering of hybrid warfare messages on social media. Further, it reveals that only functional use of social media don't predict the critical creative abilities of the students.

Table 5. Digital combating factors for hybrid warfare

\begin{tabular}{lllll}
\hline \multicolumn{4}{l}{ Model Summary } \\
\hline Model & $\mathrm{R}$ & $\mathrm{R}$ Square & Adjusted R Square & Std. Error of the Estimate \\
1 & $.568^{\mathrm{a}}$ & .323 & .316 & 4.49412 \\
\hline a. Predictors: (Constant), Creative Skills, Critical Skills, Functional Skills \\
b. Dependent Variable: Critical Creative Skills
\end{tabular}

Table 6. Digital combating factors for hybrid warfare

\begin{tabular}{lllllll}
\hline \multirow{2}{*}{ Model } & & \multicolumn{2}{l}{$\begin{array}{l}\text { Unstandardized Coef- } \\
\text { ficients }\end{array}$} & $\begin{array}{l}\text { Standardized } \\
\text { Coefficients }\end{array}$ & \multirow{2}{*}{ Sig. } \\
\cline { 3 - 5 } & & $\mathrm{B}$ & Std. Error & Beta & & \\
\hline \multirow{3}{*}{1} & (Constant) & 5.919 & .764 & & 7.749 & .000 \\
& Functional Skills & -.016 & .064 & -.023 & -.248 & .805 \\
& Critical Skills & .301 & .058 & .401 & 5.157 & .000 \\
& Creative Skills & .233 & .071 & .243 & 3.302 & .001 \\
\hline
\end{tabular}

However, critical and creative skills of social media significantly predicts the students' ability to encounter hybrid warfare messages on social media. Moreover, critical skill is a more significant factor than creative skill. Therefore, digital media literacy is the need of the time in current age of fake information and hybrid warfare.

\section{Conclusion}

Finally, it is concluded that university students of Punjab are mostly social media users, and they are equipped with basic digital media literacy skills. They are active in functional and critical use of social media messages about the security forces. They don't accept or share information against the security forces of Pakistan. They also evaluate social media messages and information on internet critically. They are aware from the fake and malicious information about the security forces of Pakistan on social media and internet. However, study also indicates that young boys and girls of universities are exposed to messages 
and information against the security forces of Pakistan. This shows that hybrid war is prevalent on social media. Therefore, this alarming situation demands the enhancement of digital media skills among the students of higher education. Moreover, critical and creative abilities of students are less as compared to the functional abilities of students in consuming social media or internet. Therefore, these abilities should be enhanced to encounter the hybrid warfare on social media and be critical to the social media messages and content against the armed forces. In sum, it can be concluded that preparation of our opinion warriors in cyberspace by enhancing social media literacy among the university students may become one of the best strategies to compete in hybrid warfare.

\section{Recommendations}

In line with the empirical findings of the study, we provide following recommendations to the policy-makers.

1. Seminars and workshops should be organized at universities to promote awareness about digital media literacy and hybrid warfare.

2. Students should be trained to evaluate social media messages critically with strategic as well as social perspectives.

3. Public relation departments of security forces should work to promote and share counter narratives on social media.

4. Training workshops about the content creation, like adobe Photoshop, Corel draw, adobe in-design, adobe audition, Microsoft publishers and movie maker software should be organized at university level.

5. Social media consumption and basic skills should be embedded in curriculum at elementary, secondary, higher secondary, and higher education in all disciplines.

6. Training workshops and courses should also be provided online.

7. Digital media literacy should also be promoted among the civil society of Pakistan to encounter hybrid warfare.

8. Lastly, females are less active and critical as compare to the male students; therefore special attention should be given to train female opinion warriors.

\section{References}

1) Martinsson J, CommGap Discussion Papers World Bank;The role of media literacy in the governance reform agenda. 2009. Available from: http:// documents.worldbank.org/curated/en/891511468331267009/pdf/503000WP0Box341ia0Literacy01PUBLIC1.pdf.

2) Koc M, Barut E. Development and validation of New Media Literacy Scale (NMLS) for university students. Computers in Human Behavior. 2016;63:834843. doi:10.1016/j.chb.2016.06.035.

3) Shao C, Ciampaglia GL, Varol O, Flammini A, Menczer F. 2017.

4) Hornik R. A strategy to counter propaganda in the digital era;vol. 14. East-Central Europe. 2016. Available from: https://www.ceeol.com/search/articledetail?id $=577026$.

5) Awan I. Cyber-Extremism: Isis and the Power of Social Media. Society. 2017;54(2):138-149. doi:10.1007/s12115-017-0114-0.

6) Svetoka S. 2016. Available from: https://www.ceeol.com/search/book-detail?id=661250.

7) Karolewski A. 2018. Available from: https://www.ceeol.com/content-files/document-699955.pdf\#page=208.

8) Biały B. Social Media-From Social Exchange to Battlefield. The Cyber Defense Review. 2017;2(2):69-90. Available from: www.jstor.org/stable/26267344.

9) Rácz A;Russia’s hybrid war in Ukraine. Breaking the enemy's ability to resist. 2015. Available from: https://www.fiia.fi/en/publication/russias-hybrid-warin-ukraine.

10) Duggan PM. Strategic Development of Special Warfare in Cyberspace. Joint Force Quarterly. 2015;79(4).

11) Nissen TE. 2015. Available from: http://www.fak.dk/en/publications/Documents/The\%20Weaponization\%20of\%20Social\%20Media.pdf.

12) L-M H, International conference Knowledge-Based Organization. Hybrid Warfare-A Form of Asymmetric Conflict. vol. 2017. De Gruyter Open. . Available from: https://doi.org/10.1515/kbo-2017-0021.

13) LIVINGSTONE S. Media Literacy and the Challenge of New Information and Communication Technologies. The Communication Review. $2004 ; 7(1): 3-14$. doi:10.1080/10714420490280152.

14) Thoman E, Jolls T. Media Literacy-A National Priority for a Changing World. American Behavioral Scientist. 2004;48(1):18-29. doi:10.1177/0002764204267246.

15) Silverblatt A, Miller DC, Smith J, Brown N. 2014. Available from: https://www.goodreads.com/book/show/553217.Media_Literacy.

16) Grizzle A, Moore P, Dezuanni M, Asthana S, Wilson C, Banda F. 2014. Available from: http://www.unesco.org/new/en/communication-and-information/ resources/publications-and-communication-materials/publications/full-list/media-and-information-literacy-policy-and-strategy-guidelines/.

17) Spante M, Hashemi SS, Lundin M, Algers A. Digital competence and digital literacy in higher education research: Systematic review of concept use. Cogent Education. 2018;0(0):1519143-1519143. doi:10.1080/2331186x.2018.1519143.

18) Eshet-Alkalai Y. Thinking in the Digital Era: A Revised Model for Digital Literacy. Issues in Informing Science and Information Technology. 2012;9(2):267276. doi:10.28945/1621. 